This item was submitted to Loughborough's Research Repository by the author.

Items in Figshare are protected by copyright, with all rights reserved, unless otherwise indicated.

\title{
Consuming sex: socio-legal shifts in the space and place of sex-shops
}

PLEASE CITE THE PUBLISHED VERSION

PUBLISHER

(C) Baptiste Coulmont and Phil Hubbard

VERSION

NA (Not Applicable or Unknown)

LICENCE

CC BY-NC-ND 4.0

\section{REPOSITORY RECORD}

Coulmont, Baptiste, and Phil Hubbard. 2019. "Consuming Sex: Socio-legal Shifts in the Space and Place of Sex-shops”. figshare. https://hdl.handle.net/2134/4409. 
This item was submitted to Loughborough's Institutional Repository (https://dspace.lboro.ac.uk/) by the author and is made available under the following Creative Commons Licence conditions.

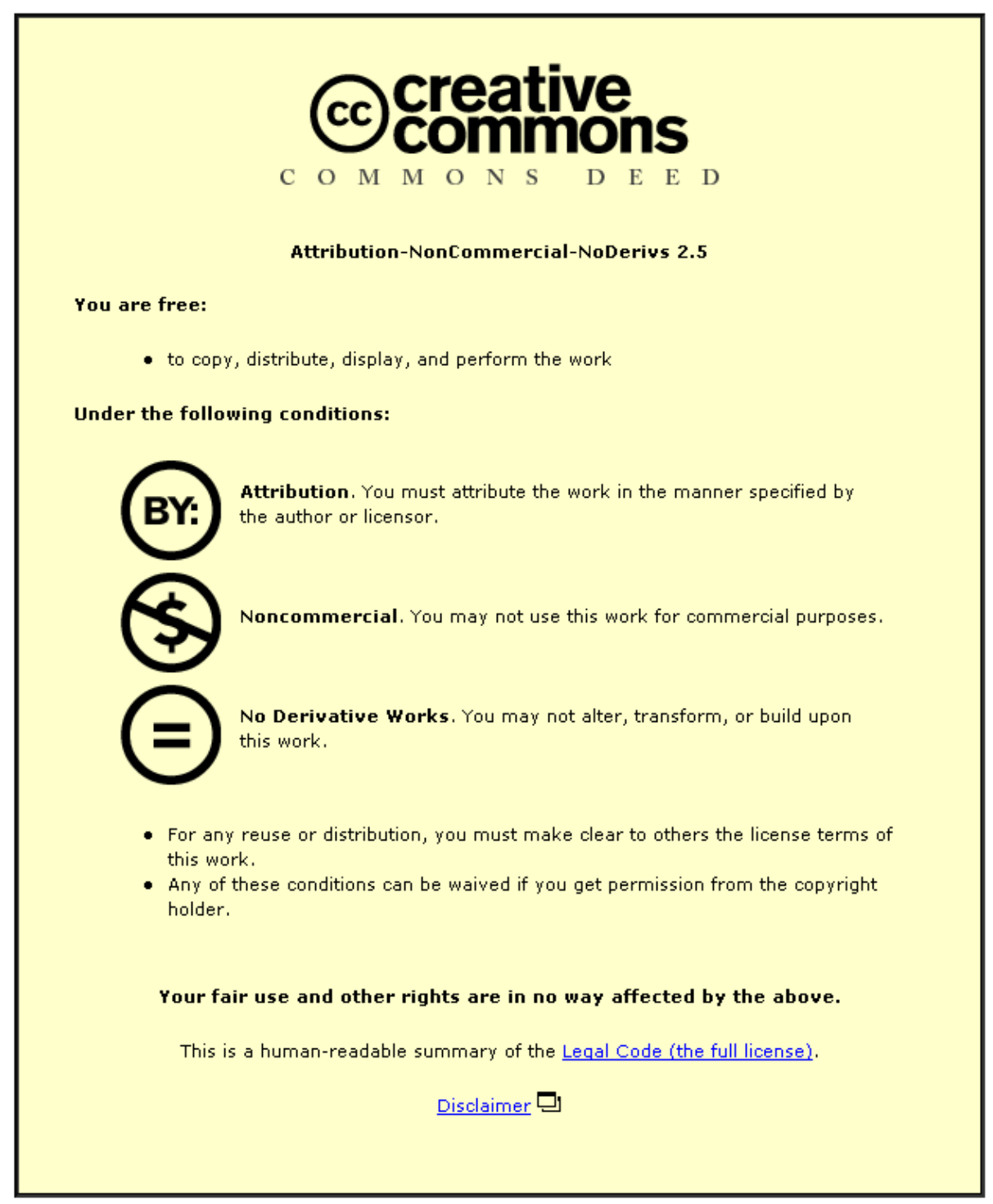

For the full text of this licence, please go to: http://creativecommons.org/licenses/by-nc-nd/2.5/ 


\title{
Consuming sex: socio-legal shifts in the space and place of sex-shops
}

\author{
Baptiste Coulmont, (University of Paris at Saint-Denis) and Phil Hubbard \\ (University of Loughborough)
}

\begin{abstract}
Pornographic and erotic materials (e.g. magazines, DVDs, sex toys. fetishwear and lingerie) have always been subject to regulation because of the perceived potential of such items to 'corrupt and deprave'. Yet the state and law has rarely sought to ban such materials, attempting instead to reduce the visibility of, and access to, them. The outcomes of such interventions have, however, rarely been predictable, something we explore with reference to the changing regulation of sex-shops in Britain and France since the 1970s. Noting ambiguities in the legal definitions of spaces of sex retailing, this paper traces how diverse forms of control have combined to restrict the location of sex-shops, simultaneously shaping their design, management and marketing. Describing the emergence of gentrified and 'designer' stores, this paper argues that regulation has been complicit in a process of neoliberalisation that has favoured more corporate sex-shops - without this having ever been an explicit aim of those who have argued for the regulation of sex retailing.
\end{abstract}

\section{Introduction}

Objects and media designed to sexually-arouse have always circulated in society, yet it was as recently as the 1970s that the sex-shop emerged in the urban West as a recognisable space of sex consumption. In effect, such shops brought together various items that had previously been sold elsewhere (e.g. through specialist bookshops, in pharmacies, lingerie shops or by mail order), offering them in an environment that left little ambiguity as to their sexual nature. Emerging in the wake of the 1960s 'sexual revolution', such spaces attracted considerable press 
interest, much of it discussing whether the widespread consumption of sexuallyexplicit materials was desirable. ${ }^{1}$ Occasionally integrated into discourses of national moral decline, for most pro-censorship groups such spaces were, however, less of a preoccupation than the increasing depiction of sex on television and in film. ${ }^{2}$ Nevertheless, locally the opening of such stores prompted considerable disquiet, with residents' groups, religious communities and business leaders often opposing them on the basis they would attract incivility, decrease property prices and lower community standards. Accordingly, the emergence of such stores prompted the introduction of regulations concerning the sale of sexual materials. As this paper describes, these subsequently created the 'sex-shop' as it is currently understood: a space forbidden to minors offering a fairly standardised repertoire of goods (videos, DVDs, magazines, vibrators, condoms, lubricants, lingerie, fetish-wear and 'poppers').

Despite growing academic interest in the consumption of pornography - especially by women ${ }^{3}$ - there have been only a handful of studies of the sex-shop as a social setting ${ }^{4}$, and even fewer considering its legality. ${ }^{5}$ In this paper, we therefore detail how the state and law have attempted to clarify what constitutes a sex-shop and impose particular conditions on its existence. Here, we focus on sex-shops in Britain and France, using judicial, police and media archives to detail the varied legal and extra-legal practices that have allowed the opening of particular types of stores in certain spaces, but repressed others. Given the French and British legal systems are substantially different, it might be anticipated that the regulation

\footnotetext{
${ }^{1}$ Coulmont, B. Sex-shops: une histoire francaise (2007) Paris: Editions Dilecta

${ }^{2}$ Greek, C.E. and Thompson, W. Anti-pornography campaigns: saving the family in America and England (1992) International Journal of Politics, Culture and Society 5 601-609.

${ }^{3}$ Molina, D. and Schmidt, R. It's a business doing pleasure with you: Sh! A women's sex-shop case (1997) Marketing, Intelligence and Planning 15 352-357; Smith, C. Designed for pleasure: style, indulgence and accessorized sex (2007) European Journal of Cultural Studies 10 167-184.

${ }^{4}$ Stein, M. The ethnography of an adult bookstore: Private scenes and public places (1997) Lewiston, NY: Edwin Mellen; Berkowitz, D. Consuming eroticism: gender performances and presentations in pornographic establishments (2003) Journal of Contemporary Ethnography 35 583-606.

${ }^{5}$ Manchester, C. Sex-shops and the law (1989) Chichester: Gower; Goudie, A. Local authority licensing of sex-shops and sex cinemas (1986) London: Sweet and Maxwell.
} 
evident in the two nations would also diverge. To the contrary, we suggest that in both jurisdictions there have been similar shifts from police repression and surveillance to more diffuse forms of commercial regulation. Making this argument, we note the legal ambiguity about what constitutes a sex-shop, and suggest this lack of clarity has allowed for the emergence of retail outlets whose legal status remains unclear but which adhere to certain shared styles of management. In demonstrating this, we argue that the shape and form of the contemporary sex industry is partly the outcome of socio-legal processes whose effects are rarely predictable and often contradictory.

\section{Two structures of regulation}

Given pornographic materials were widely-available before the 1970s, often in specialist 'gentleman's bookshops', ${ }^{6}$ it is difficult to be precise about when shops selling a range of sex materials first emerged in either Britain or France. But it was in the 1970s that the media began to comment on the phenomenon, with the concept of the sex-shop entering the popular lexicon. Significantly, French shops were identified through the anglicized term 'sex-shop', which was a way for owners to signify their modern character but for opponents became a way of characterising them as non-French, and hence a threat to the moral values of the nation-state ${ }^{7}$ : in Britain, it was more common for such shops to be named as Adult or Private Shops, albeit the term sex-shop was used generically to label this category of premise.

The underlying causes of anxiety about sex-shops are open to multiple conjecture, but certainly relate to modern assumptions that sex is something that can be

\footnotetext{
${ }^{6}$ Kent, T. and Brown, R B. Erotic retailing in Britain 1963-2003 (2006) Journal of Management History 12 199-211.

${ }^{7}$ Coulmont op cit, p.18.
} 
enjoyed in the private/personal sphere, but when encountered in the public realm disturbs as much as excites. Advertised as stores where items are valued for erotic potentiality, sex-shops transgress social convention by bringing 'erotic reality' into the realms of the quotidian. ${ }^{8}$ This given, sex-shops have been variously depicted as spaces of deviance, immorality and vice, with academic discussions of sex retailing until recently played out solely within 'deviance studies', explicitly-figuring patrons as a specific subset of the population. ${ }^{9}$

Whatever the roots of hostility to sex-shops were - and it should be noted that opposition has often involved 'unlikely' alliances between church groups, feminists and local residents ${ }^{10}$ - the initial number of stores was certainly limited, with few outside the major metropolitan centres. In both France and Britain it was the proliferation of sex-shops in the national capital that prompted most debate, with anxieties about sex-shops mapped onto, and out of, specific urban spaces. In Britain, for example, it was in Soho that local business groups and residents first expressed anxieties about the emergence of stores selling pornographic materials, voicing concerns that such businesses, alongside sex cinemas and 'strip shows', were displacing independent local businesses (e.g. delicatessens, restaurants, craft industries).${ }^{11}$ However, such discourses of opposition became mirrored in the provinces as leading operators (notably Conegate) began to target all towns with a population of over 100,000, with around 120 sex-shops open by the end of the 1970s. ${ }^{12}$

\footnotetext{
${ }^{8}$ Berkowitz, op cit, p.584..

${ }^{9}$ Karp, D.A. Hiding in pornographic Bookstores: A Reconsideration of the Nature of Urban Anonymity (1973) Urban Life 1 (4) 427-451; Tewksbury, R. Patrons of Porn: Research Notes on the Clientele of Adult Bookstores (1990) Deviant Behavior 11 259-271

${ }^{10}$ Manchester (1986) op cit. p.74.

${ }^{11}$ Mort, F. Striptease: the erotic female body and live sexual entertainment in mid-twentieth century London (2007) Social History 32 27-53.

${ }^{12}$ Manchester op cit p.78.
} 
Because sex-related uses do not constitute a distinct category in the Use Classes Order in Britain, there was no possibility of using US-style zoning powers to prevent sex-shops opening in specified areas. ${ }^{13}$ Further, if an existing retail business converted to a sex-shop there was no need to apply for change of use. ${ }^{14}$ While the 1959 Obscene Publications Act justified police raids and stock seizure, changing moral standards meant that much of the material seized was judged by the Director of Public Prosecutions as unlikely to be considered by a jury as 'corrupting', with successful prosecutions becoming scarcer through the 1970s. Likewise, when the police confiscated stock, it was often replaced within days, making police actions futile.

Given the obvious limitations of both criminal and planning law for controlling sex-shops, and amidst rising concern among Soho residents in particular, Westminster City Council petitioned central government for powers to exercise control over sex-businesses, initially by proposing a change to the Use Classes Order. Gradually, however, the notion that licensing might provide a more effective basis for control emerged, given premise licensing had been the main mechanism by which locally-contentious land uses such as spaces of gambling and drinking had been regulated in Britain as far back as the nineteenth century. It was during the second reading of the Local Government (Miscellaneous Provisions) Bill - which contained provisions dealing with the licensing of night cafes, tattooing and ear-piercing parlors - that MPs raised the possibility that such licensing be extended to sex-shops. The strength of feeling was such that the government brought forward amendments at the report stage, effectively introducing a system of local

\footnotetext{
${ }^{13}$ Papayanis, M. Sex and the revanchist city: zoning out pornography in New York (2000) Environment and Planning D: Society and Space 18 341-354; Tucker, D. M. Preventing the secondary effects of adult entertainment establishments: Is zoning the solution? (1997) Journal of Land Use and Environmental Law 12 383-431.

${ }^{14}$ Forward planning can theoretically be used to identify areas for sex-related uses, allowing the refusal of planning permission for a sex-shop outside such areas.
} 
sex-shop licensing through the provisions of Sections 2 and 3 of the Local Government (Miscellaneous Provisions) Act 1982. ${ }^{15}$

This new system allowed any local authority to issue licenses for 'any premises, vehicle, vessel or stall used for a business that consists to a significant degree of selling, hiring, exchanging, lending, displaying or demonstrating sex articles or other things intended for the purpose of stimulating or encouraging sexual activity or acts of force or restraint which are associated with sexual activity.' ${ }^{16}$ Under the Act's provisions, no person was permitted to operate a sex-shop except in accordance with the terms of a licence granted by a council. The grant of the license did not affect what could be sold, since items sold were still subject to obscenity legislation However, the grant of a license did affect the quantity of sex-related goods sold, since the license permitted the selling of sex articles 'to a significant degree'. The one exception to this preoccupation with quantity rather than quality was that the sale of R18 (restricted 18) videos required a license. ${ }^{17}$

Though the Act allowed local authorities little discretion over the nature of materials sold in sex-shops, it permitted the imposition of conditions prohibiting display of products in shop windows, refusing access to under-18s and restricting opening hours from 9am to $6 \mathrm{pm}$ (or rarely $7 \mathrm{pm}$ or $8 \mathrm{pm}$ ). The new act also allowed refusal of a license on a number of grounds, such as the 'character of the applicant' or the unsuitability of the location. ${ }^{18}$ Backed-up with threats of fine and imprisonment for running a sex-shop without a license, and, latterly, the enforced

\footnotetext{
${ }^{15}$ The Act was extended to Northern Ireland by the Local Government (Miscellaneous Provisions) (Northern Ireland) Order 1985 No 1208 (NI 15).

${ }^{16}$ Local Government (Miscellaneous Provisions) Act 1982, Schedule 3, Paragraph Four

${ }^{17}$ R18 videos/DVDs are classified by the British Board of Film Classification as 'not to be supplied to any person under 18 and only to be supplied through a licensed sex-shop' (Video Recordings Act, 1984, sec 7.2.c)

${ }^{18}$ Hubbard, P., Matthews, M. and Scoular, J. Controlling sexually oriented businesses: law, licensing and the geographies of a controversial land use (2009) Urban Geograpby 30 (2) 185-205.
} 
closure of unlicensed premises ${ }^{19}$, the 1982 Act gave considerable powers to local authorities. Controversially, it also allowed local authorities to generate considerable revenue through variable fees for sex-shop licenses (e.g. an annual license costs $£, 1500$ in Peterborough, $£_{4} 4500$ in Salford, $£_{5000}$ in Liverpool, £,12500 in Glasgow and $£_{20000}$ in Westminster). ${ }^{20}$

However, the effectiveness of licensing was initially questioned given confusion about which stores required licensing, with a small number of unlicensed stores continuing to trade by ensuring sex-related items did not represent a 'significant' proportion of their trade (stocking large numbers of remaindered nonpornographic novels). The legal interpretation of what constituted a 'significant proportion' was clarified in 1985 when Lambeth Borough Council unsuccessfully charged a newsagent who sold pornographic magazines with running a business with 'more than trifling sexual content', despite these constituting only one percent of his stock. On appeal, the Courts ruled the 1982 Act did not 'set such a low standard' or justify intervention where sexual content was being sold by 'an otherwise inoffensive businesses'. Subsequently, it has been assumed the proportion of sexual goods should normally exceed other aspects of the business. ${ }^{21}$

No licensing took place in France, rather a steady accumulation of local and national legislation. During the post-war years, the principal weapon against pornography was the police's use of l'outrage aux bonnes moeurs (outrages against morality), with the exchange of objects outside the boundaries of 'common' morality potentially leading to a fine and imprisonment. But from the 1960s, judges were less inclined to condemn: more than 350 people were fined or jailed in 1962,

\footnotetext{
${ }^{19}$ Under the provisions of the City of Westminster Act 1996.

${ }^{20}$ This fee is supposed to represent the costs of operating the licensing system: however, one local authority - York - sets fees to reflect the perceived profitability of the stores concerned.

${ }^{21}$ Lambeth London Borough Council v Grewal (1985) 84 LGR 538, 82 Cr App Rep 301, 150 JP 138 (1986) Crim LR 260. See also Watford Borough Council v Private Alternative Birth Control Information (1985) Crim LR 594, which concluded there could be no single definition of what a 'significant degree' is.
} 
but only around 50 in $1978 .^{22}$ 'Les moeurs' (morals) were deemed to be evolving rather too rapidly, with the common morality of French citizenry increasingly described by the courts as a problematic basis for legal action (the 'outrage aux bonnes moeurs' hence disappeared from the French Penal Code in 1994).

But as the 'outrages aux bonnes moeurs' got weaker, stores opened which did little to disguise the sexual content of their stock. The first French 'sex-shops' opened in 1969 and 1970 at the centre of touristic, civic and intellectual Paris (e.g. the Quartier Latin, the Champs Elysées). They sold objects that were legal (small vibrators, condoms, various novelties) as well as posters, small artistic statues, and books deemed to be unfit for minors but sellable to non-minors under certain rules. But even if, separately, such objects were legal, their gathering in a single outlet created tensions. From the beginning, protests were voiced by journalists, politicians and 'concerned citizens' in both newspapers and town halls. For example, in 1969 the conservative daily Le Figaro proclaimed 'Eroticism is threatening Paris!" ${ }^{23}$ when a store opened under the name 'Sexologie, insolite'. The owner was described as 'a Chinese' and the model as 'Copenhagen': French national morality was obviously threatened. Elected Parisian officials angrily voiced their opposition, asking the Prefect for 'extremely drastic, forceful measures' against sex-shops. ${ }^{24}$

The consequence of such opposition was a two-pronged legal and administrative action. In September 1970, an order (ordonnance) of the Paris Prefect created a regulation for bookstores that openly-advertised their sexual goods ${ }^{25}$. This 'ordonnance' created a new class of stores on which the police could act. To counter

\footnotetext{
${ }^{22}$ Compte général de l'administration de la justice criminelle et de la justice civile et commerciale (Statistical Yearbook of Justice).

${ }^{23}$ Le Figaro (1969) 26 November. A copy of the article was found in the proceedings of a trial : Archives de Paris, 1886W 11.

${ }^{24}$ Bulletin municipal officiel de la ville de Paris (1970) 6 March, p.401.

${ }^{25}$ ibid 16 September, p.1505.
} 
the weakening of the ' $O B M$ ', the Prefect based this decree on another set of laws: namely, the 1949 regulation that created a set of books forbidden to minors. These books could not be advertised, nor made directly available (being stored in closed cabinets). The titles of such books were regularly published in the Journal Officiel, the public gazette of the French Republic. The Prefect accordingly adopted the principle that if certain stores specialized in the sale of books forbidden to minors, then such stores should also be off-limits for minors, with the police ensuring this. ${ }^{26}$ Further, because sex-shop windows became increasingly 'graphic' with the progressive liberalization of magazine content, the Prefect ordered a blackening or opacification of the windows in $1973 .{ }^{27}$ The rationale was based on an extension of the previous 'ordonnance', arguing that minors should not be able to see what was for sale in the stores. But while the aim was to hide the stores' paraphernalia and restrict it to the private realm, it conversely lent the stores themselves heightened visibility as they were the only ones without real windows. In so doing it created something of a mystique around sex-shops, and created them as taboo - and potentially erotic - spaces. It is hence possible to trace the production of a specific cultural form defined by the law: after all, law is not only repressive - even when its stated aim is to repress - it is also expressive (affirming a common good) and productive (enacting material constraints). The law effectively bought the 'pornographic bookstore' into being as a distinctive legal, physical and even moral category - one so 'solid' that it persisted even when 'bookstores' stopped selling books in favour of videos and then DVDs.

\footnotetext{
${ }^{26}$ This was a local municipal law erroneously thought to be enforceable throughout France. In fact, the Minister of Interior declared in 1971 that no new national law was required as the police had sufficient powers. The Minister of Justice concurred: the sex-shop owners, he declared 'are probably aware of their precarious situation' and 'discipline themselves' - see Journal officiel de la République française, Débats parlementaires, Assemblée nationale, (1971) 21 August, p.3956, Réponse du Ministre de la Justice à la question nº19210 du député Brocard.

${ }^{27}$ Bulletin municipal officiel de la ville de Paris (1973) 16 September, p.1782.
} 


\section{Framing the discourse of protection}

In societies where the consumption of sex is regarded as most appropriate in the context of private sexual intimacy, sex retailing has always posed significant questions about the place of pornographic materials. However, the impossibility of defining some objects as unambiguously obscene (and hence likely to corrupt) has instead encouraged legislation designed to prevent them being seen by 'those whose minds are open to immoral influences. ${ }^{28}$ This implies the state and law has been keen to uphold liberal principles as they relate to the (private) sexual body, following the principle that power should only be exercised over an individual against their will if it is in the interests of preventing harm to others. Within the EU, Article 10 of 1998 Human Rights Act has become significant in this respect, implying that the right to freedom of expression can be extended to those who distribute, buy or look at pornography. Yet the same act argues this can be subject to appropriate restriction - a caveat that suggests that a consumer's right to access pornography should not be allowed to impinge on the lives of those who do not wish to. This argument was indeed made by those feminist movements which sought to condemn sex-shops in the late 1970s, with 'Take back the night' demonstrations ('La nuit est à nous' in France) implicating sex-shops in wider process of sexual objectification that limited that women's rights to public space. ${ }^{29}$

Perhaps informed by such arguments, the state and law has accordingly sought to prevent sex-shops intruding on the lives of those who do not want to be confronted by sexual commerce. ${ }^{30}$ In Britain, the most obvious manifestation has been the licensing conditions that demand 'the displays of articles sold at the

\footnotetext{
${ }^{28}$ Ibid, p.35.

${ }^{29}$ See Walkowitz, J. R. City of Dreadful Delight. Narrative of Sexual Danger in Late-Victorian London (1992), Chicago, The University of Chicago Press, 235-236. For French feminist actions against sex-shops, see Bibliothèque Marguerite Durand (Paris) (1978), Folder 396 FEM.

${ }^{30}$ See Cornell, D. The Imaginary Domain: Abortion, Pornography and Sexual Harassment (1997) New York, Routledge for a politicized discussion of the importance of zoning pornography rather than outlawing it outright.
} 
premises shall not be visible at any time to persons outside the building'. This desire for strong separation of the public realm and the publicly-accessible space of the sex-shop is underlined by guidance stipulating that 'the external doors shall be fitted with automatic closing devices'. In France, judicial decisions in 1972 and 1978 likewise established the 'sex-shop' as a black box, arguing that if it is impossible to see the store's content from the street, and if people are sufficiently aware of the character of the store before entering, the sex-shop cannot constitute an 'outrage aux bonnes moeurs. ${ }^{31}$ Such organisational devices ensure those who do not wish to be consumers of sexual materials are not confronted with such objects, while the widespread adoption of names such as the 'Private Shop' in Britain further protecting the prudish. ${ }^{32}$

In a wider sense, allowing sex-shops to persist under certain conditions rather than banning them outright reflected wider shifts in the regulation of sexuality: Michel Foucault, in a 1978 debate, spoke of a transition from a prohibition of certain acts to the protection of society from 'dangerous individuals'. He termed this 'a new regime for the supervision of sexuality' whose function 'is not so much to punish offenses against these general laws concerning decency, as to protect populations and parts of populations regarded as particularly vulnerable':

In the past, laws prohibited a number of acts... Now what we are defining and, therefore, what will be found by the intervention of the law, the judge, and the doctor, are dangerous individuals. We're going to have a society of dangers, with, on the one side, those who are in danger, and on the other, those who are dangerous. And sexuality will no longer be a kind of behavior hedged-in by precise prohibitions, but a kind of roaming danger, a sort of omnipresent phantom...It is on this shadow, this phantom, this fear that the

\footnotetext{
${ }^{31}$ Cour d'Appel de Besançon, (1972) 9 May, Ga\%: Pal. 1972.2.558 note Lambert, and Chambre Correctionnelle de Reims (1978) 7 October, Ga\%. Pal. 1978.2.somm.122.

${ }^{32}$ Kent and Brown op cit, p.193.
} 
authorities would try to get a grip through an apparently generous and, at least general, legislation. ${ }^{33}$

Accordingly, the core of French regulation was protection of the child, firstly because pornographic books had been defined as 'children-adverse' and secondly, because children were increasingly depicted as 'endangered. ${ }^{34}$ This was explicit in political debates, with one MP arguing that while the law 'forbids the implantation of bars and cafés too close to schools, the implantation of 'sex-shops' is certainly more dangerous (redoutable) than that of cafés for the moral security of children. ${ }^{35}$ From the late 1970s, French politicians increasingly argued for tighter regulation of sex-shops to prevent them opening near schools, arguing that, like bars, sex-shops should be considered very dangerous for some people, and especially the young.

Here, there was an implicit understanding that 'too early an exposure' to sexual content might inhibit normal sexual development or convey a 'distorted view of sexuality' in which recreational notions of sex would overwhelm ideas of commitment and emotional reciprocity. ${ }^{36}$ The incompatibility of sex commerce and childhood was emphasised time and again by French judges in lawsuits: in a suburb of Paris, Houilles, the judge remarked that 'a bus stop serving the schools is located precisely in front of this store ${ }^{37}$. In Avignon, the location of a sex-shop was considered 'incompatible' with 'an orthodontics practice welcoming a clientele of young children 38 . In Rouen some children were passing in front of a store twice a day, risking 'moral and psychological damages to those minors, who will be

\footnotetext{
${ }^{33}$ Foucault, M. Sexuality Morality and the Law, in Kritzman, L. D. (ed.) Michel Foucault. politics, philosophy, culture: interviews and other writings (1988) New York: Routledge.

${ }^{34}$ On obscenity law and the protection of children, see Heims, M. Not in Front of the children (2001) Chicago, Chicago University Press.

${ }^{35}$ Journal officiel de la République française (1986) 10 February, p.508, question nº77934 du député Édouard Frédéric-Dupont.

${ }^{36}$ Manchester et al, op cit, p.118.

${ }^{37}$ Cour administrative d'appel de Versailles (2008) 13 March [N06VE01662]

${ }^{38}$ Cour d'appel de Nimes (1998) 28 September [N97/5355]
} 
exposed from a young age to images or messages from the pornography. ${ }^{39}$ The judge noted that the images were not pornographic in themselves, but that the shop's visibility might normalise 'la pornographie'.

In Britain too, a major aim of licensing has been the protection of children. However, this is not explicit in the 1982 Act, and the justification for excluding under-18s from sex-shops is not clear given the Sexual Offences Act 2003 seeks to protect only under-16s. ${ }^{40}$ However, the fact many stock R18 DVDs suggests that the legislation surrounding sex-shops took its lead from the existing BBFC regulations that stipulate only over-18s can be exposed to 'real' as opposed to simulated sex. To these ends, standard conditions on sex-shops in Britain suggest:

At each entrance there shall be prominently displayed so as to be visible at all times to persons approaching the premises a notice prohibiting entry to all persons under 18 years of age. Such a Notice shall be in letters at least $50 \mathrm{~mm}$ high and $6.25 \mathrm{~mm}$ thick and shall be in dark letters on a light background. The Licensee of every premises licensed as a sex-shop shall ensure that all persons employed on the premises are aware of the age restriction on clients and...exclude or remove from the premises any person attempting to evade the restriction. ${ }^{41}$

Despite such efforts to ensure these spaces are off-limits to minors, the vulnerable child remains a potent figure in debates around sex-shops, with opposition to their opening often couched in terms of potential impact on children. For example, Trafford Council's refusal of a licence for a sex-shop in 2005 was portrayed in the

\footnotetext{
${ }^{39}$ Cour d'appel de Rouen (2003) 29 April [N02/03110]; see also Tribunal de Grande Instance de Lyon, Ordonnance de référé (2002) 7 June 7 [N02/01541]

${ }^{40}$ The 2003 Sexual Offences Act makes it an offence to intentionally show another person an image of sexual activity where a person is under- 13 or where the person is under- 16 and there is no reason to believe they are over 16.

${ }^{41}$ Standard conditions for sex-shop license, as issued by all local authorities who have adopted a sex-shop licensing scheme, paragraph 4.
} 
local media as a victory for a local schoolgirl, who had written (alongside other objectors) that 'This shop will attract paedophiles, perverts and rapists... As well as the fact that the crime rate may well rise, we will be letting children in the community get contaminated. ${ }^{42}$ Invoking exclusionary metaphors, the case for repression was clear and, in this instance, a local councillor claimed 'the large concentration of schools in the area, several residential streets, and a popular nursery' all made the refusal 'common sense'. Similarly, a successful campaign against a Kendal sex-shop was led by two 'divorced women who have eight sons between them', who claimed 'the job of being single parents would only be made harder if the shop opened' as 'youngsters would be tempted to go inside and the shop would prompt them to think about sex'. ${ }^{43}$

Such license refusals, and related appeal cases, suggest that while councils cannot refuse licences on moral grounds per se, they can do so if 'the sort of people likely to be in the locality or vicinity are more liable than most to find a sex establishment in that location intrinsically objectionable, morally offensive [or] intrusive upon their sensibilities.' Indeed, when adjudicating an appeal case against Newham Council, Justice Brown stated 'the only reason I can envisage why sex establishments should ever be regarded as inappropriate in a given locality, assuming always that they satisfy the requirements of planning legislation, is because they may be thought to constitute a temptation to those in the area, perhaps particularly children, to sample their wares. ${ }^{44}$ Although the argument that customers of sex-shops might be a danger to young people has not been legally supported given the lack of reliable evidence that sexual attacks are higher around such premises ${ }^{45}$, this has clearly not prevented opponents of sex-shops making allegations they render children susceptible to physical harm.

\footnotetext{
${ }^{42}$ Manchester Evening News (2005) 30 September, p.19.

${ }^{43}$ Westmorland Gazette (2005) 7 October, p.2.

${ }^{44}$ Brown, J. cited in R v London Borough of Newham ex parte Sheptonhurst Ltd Queen's Bench Division (Crown Office List) (1987) CO/980/85.

${ }^{45}$ Linz, D., Paul, B. and Yao, M. Peep show establishments, police activity, public place and time
} 
The discourse of youth vulnerability is similar in the French case, with children regularly depicted as potential victims of sex-shop customers, ('animals, would-be paedophiles and perverts'). ${ }^{46}$ This argument is the correlate of a shift in focus: at the beginning of the 1970s, journalists and elected officials stigmatized the sexshop owners as professional perverts, or 'libertines', but those owners could easily be depicted as an isolated individuals. Later, the focus shifted to customers, who were depicted as more numerous yet not readily identifiable (being indistinct from any other 'man on the street'). For such reasons, debates around the legal protection of children in France regularly invoked discussion of sex-shops. The drafting of child protection laws (1996-1998, 2007) effectively crystallised this, conflating the protection of children with the protection of neighbourhood spaces: residents and children alike spoke in the same sentence of protecting their children and 'their' streets.

\section{Location, location, location}

Given the stated aim of regulating sex-shops has been protecting particular 'vulnerable' populations whilst respecting the rights of consenting adults to consume sexual materials, limiting them to specific locales has been a key regulatory tactic. In Britain, such spatial control is facilitated by the licensing system, which encourages local authorities to consider the character of the relevant locality and the uses to which any premises in the vicinity are put. Refusal of a sexshop license is thus possible if 'the number of sex establishments in the relevant locality at the time the application is made is equal to or exceeds the number which the authority consider is appropriate for the locality', with the local authority able to 
decide that none may be appropriate. ${ }^{47}$

Despite this, in practice it remains difficult for local authorities to state there is no suitable location for a sex-shop within the entire borough, albeit this was the line adopted by many local authorities in the 1980s. For example, Cheltenham Borough Council rejected numerous applications for sex-shops arguing that those in the town who wished to visit such premises could do so by travelling to neighbouring Gloucester. ${ }^{48}$ By 1983, Swansea and Chester, Preston, Trafford, Watford and Havant had all refused licenses on these grounds. But subsequent to the passing of the EU 1998 Human Rights Act, and particularly Article 10, most local authorities have not sought to enforce a total ban on sex-shops given this might be seen to reduce freedom of expression. In some cases, this has witnessed local authorities that previously stated they would not grant licenses recanting (e.g. Richmond Council granted a license to a sex-shop on Kew Road in December 2004 despite having earlier stated that such establishments would not be suitable anywhere in the borough). ${ }^{49}$ However, how far freedom of expression extends to the right to sell pornography is debatable, given all freedoms are deemed to carry responsibilities including the 'prevention of disorder and crime' and the 'protection of health and morals. ${ }^{50}$ Rejecting an appeal against license refusal made under article 10 (b) and 1(c) of the First Protocol to the European Convention for the Protection of Human Rights and Fundamental Freedoms 1950 (as set out in Schedule One to the Human Rights Act 1998), Lord Hoffmann indeed stressed that 'the right to vend pornography is not the most important right of free expression in a democratic

\footnotetext{
${ }^{47}$ Local Government (Miscellaneous Provisions) Act (1982) Schedule 3, section 12, paragraph 5 (a).

${ }^{48}$ Quietlynn Limited v Cheltenham Borough Council Court Of Appeal (Civil Division) LJJ The Times 25 July 1986, 85 LGR 249.

${ }^{49}$ Sex-shop is inappropriate in our community say residents Richomd and Twickenham Times Saturday (2005) 10 Dec, p.7.

${ }^{50}$ Article 10 (2) Human Rights Act (1998).
} 
society and the licensing system does not prohibit anyone from exercising it - it only prevents him $\left[s i d\right.$ from using unlicensed premises for that purpose. ${ }^{51}$

Given this, it has been deemed insufficient for the licensing authority to say a license would be inappropriate without telling the applicant what it is about an area that makes a sex-shop inappropriate, putting the onus on the local authority to justify refusal. ${ }^{52}$ Here, reasonable grounds for refusal appear to include the presence in the locality of schools or nurseries, places of public worship, 'family housing' and even 'the presence of a number of shops which would be of particular attraction to families and children. ${ }^{53}$ Nevertheless, questions remain as to what 'the relevant locality' means, as although this is straightforwardly-defined as the 'locality where [premises] are situated', judicial rulings suggest this is 'to be decided on the particular circumstances of a particular application. ${ }^{54}$ Localities have hence been defined variously as approximately 'one quarter of a mile"55 and 'one-third of a mile ${ }^{56}$ around a sex-shop, whilst some local authorities stipulate in their general licensing policies that objections to the opening of a licensed premise will be ignored if they originate from residents who live more than one hundred metres from a premise (the implication being that beyond this distance, they could not be directly affected).${ }^{57}$ Again, the courts have left such questions a matter for discretion, suggesting a locality cannot be defined with any precision, being 'highly dependent on local knowledge. ${ }^{58}$ This type of discretion contrasts with the rigid

\footnotetext{
${ }^{51}$ Miss Behavin' Ltd v Belfast City Council (2007) UKHL.

${ }^{52}$ R v Birmingham City Council, ex parte Quietlynn Ltd [1983] LGR 461.

${ }^{53}$ Miss Behavin' Ltd v Belfast City Council (2007) 3 All ER 1007.

${ }^{54}$ Quietlynn Limited v Peterborough City Council; Quietlynn Limited v Northampton Borough Council; Quietlynn Limited v City of Worcester; Quietlynn Limited v City of Birmingham; Quietlynn Limited v Tunbridge Wells Borough Council; Quietlynn Limited v Cheltenham Borough Council Court Of Appeal (Civil Division) Sir John Donaldson Mr, Purchas And Stocker LJJ The Times (1986) 25 July, 85 LGR 249.

${ }^{55} \mathrm{R} v$ Leeds City Council, ex parte Quietlynn Ltd Court Of Appeal (Civil Division) LJJ The Times (1986) 25 July, 85 LGR 249.

${ }^{56} \mathrm{R}$ v Peterborough City Council, ex parte Quietlynn Ltd Court Of Appeal (Civil Division) LJJ The Times (1986) 25 July, 85 LGR 249.

${ }^{57}$ Manchester et al (2007) op cit,, p.224-225.

${ }^{58} 4$ Wins Leisure ltd v Blackpool Council (2007) EWHC 2213, para 8.
} 
zoning powers typically employed in the US, where sex-shops are typically forbidden within 1000 feet of one another, schools and religious facilities.

In contrast, French regulation appears more influenced by US zoning laws than British licensing legislation. Indeed, continuing outrage during the 1980s lead some French MPs to ask for a national law restricting where sex-shops could open and, from 1987, new stores were forbidden within 100 metres of any school - a law that imposes considerable restrictions given the sheer density of schools in many French towns. ${ }^{59}$ The represents what could be called 'inverse zoning' - 'inverse' because, contrary to US-style zoning, the zones are not precisely drawn on a map, and identifying the forbidden zone is left to the would-be storeowner (who has to make sure no school is located near the prospective location). It means that, contrary to US-style zoning, there is no published information on where new sexshops can be opened, with no municipal department charged with gathering the relevant information. Even a list of addresses of 'établissements d'enseignement is difficult to find, meaning that citywide mappings of possible sex-shop locations cannot be attempted. The result, as Robert Badinter, a senior French senator, has observed, is a de facto prohibition of sex-shops in city centres. ${ }^{60}$

The new law thus represented a shift from local 'arrangements' (including chronic police surveillance and veiled threats of administrative closure) to a national law predicated on more universal notions of spatial order. ${ }^{61}$ Yet, as had been the case for the Prefect of Paris in 1970 and 1973, MPs seemed to feel a need to base their regulation on the protection of something 'fixed' (i.e. a school building in which

\footnotetext{
${ }^{59}$ Article 99, loi n87-588 du 30 juillet 1987 portant diverses mesures d'ordre social Journal officiel de la République française (1987) 31 July, p. 8583. This article was modified by Article 6, loi n 2007293 du 5 mars 2007 réformant la protection de l'enfance Journal Officiel de la République française (2007) 6 March, p.4215.

${ }^{60}$ French Senate (1997) 30 October session http://www.senat.fr/seances/s199710/ s19971030/sc19971030014.html (accessed 4 February 2009).

${ }^{61}$ Journal officiel de la République française (1978) 18 February, p.584, question n44323 of M.P. Valleix to the Minister of Interior.
} 
pupils from the age of 3 to 18 years are taught) rather than children themselves. This law hence changed the space being regulated from the sex-shop to the school and neighbourhood around the school. As part of this neighborhood-based surveillance, the local 'associations de parents d'éleves' (associations of pupils' parents, present in each and every school in France) were given the possibility to sue if a sex-shop tried to open nearby. Yet existing sex-shops were not targeted, and sometimes benefited from the elimination of would-be competitors, although profits were checked by other initiatives. For instance, from 1987 the Ministry of Finance enforced an over-taxation of 'every commercial operation realized in stores forbidden to minors', targeting boutiques $d u$ sexe. ${ }^{62}$ This meant that books, magazines or condoms were liable to 5\% VAT in most stores but 33\% VAT in a sex-shop. ${ }^{63}$ Simultaneously, rising rents made some businesses less viable. For a few years, sexshops resisted the gentrification of the centre of Paris, though the purchase of a few stores on rue Saint-Denis around 2003 by a public-private joint venture (called SEMAEST) signalled the beginning of the end for many sex-shops in the capital.

\section{Commercial regulation and self-regulation}

Attempts to regulate sex-shops - whether through censorship, licensing or planning controls - are essentially about boundary drawing, making clear where and when pornography can be bought and sold. However, in making such distinctions, Valverde argues that the state draws not on a repository of evidence about the harm that is caused by buying pornography, but rather a series of prior legal judgments in which the potential risks of opening a sex-shop are deliberated. In such ways, Valverde shows that the knowledges on which decisions about the appropriateness of a sex-shop in a particular locality are made may be sufficient for

\footnotetext{
${ }^{62}$ Bulletin officiel des impôts, $\mathrm{n}^{\circ} 25$ (1987) 16 February and Journal officiel de la République française, Article 42.I, Loi n 86-1317 du 30 décembre 1986 de finance pour 1987 (1986) 31 December, p.15826

63 The income raised was intended to help fund local museums.
} 
legal purposes, but lack the objectivity that one might associate, for example, with social science research that seeks to establish causality. This stresses that the knowledge that informs the regulation of sex-shops is a curious hybrid based on claims to knowledge in which the opinions of elected governors and interested parties' are privileged over factual evidence. Furthermore, given 'sex-shops' have never constituted a pressing social problem on which there has been social consensus, these hybrid knowledges are the result of 'piecemeal' pronouncements that lack co-ordination.

This hybridity, and the entwining of the moral and legal, means it is never entirely clear where and how pornography may be sold. One obvious example of this is the definition of a sex-shop itself, with Valverde arguing that while 'as a matter of urban experience it is not difficult to distinguish a convenience store that sells porn from a porn bookstore', the law cannot offer such a clear distinction. This is because while pornography is defined in Britain as any object intended for the purpose of stimulating sexual activity, and in France as a publication unsuitable for children, it is not pornography per se that is the regulatory object; rather, the presence of pornography is 'merely a clue to the character of the business in question'. And, as Valverde continues, 'great imprecision is found at the key switchpoint linking the publications to the business ${ }^{64}$ given a sex-shop is defined as one having a 'significant proportion' of its stock in adult publications or having as its 'principal activity' the selling of such publications.

This said, there remains significant discretion for local authorities in Britain to decide which shops require a sex-shop license. For example, it is notable that in some towns (e.g. Bristol) Ann Summers shops selling sex toys, lingerie and soft core DVDs but no R18 videos are still required to possess a sex-shop license on the basis that a significant proportion of their stock is sex-related. In others,

\footnotetext{
${ }^{64}$ Valverde, M. Authorising the production of urban moral order: appellate courts and their knowledge games (2005) Law and Society Review 39 (2) 419-456.
} 
licensing officials are aware there are sex superstores or lingerie stores which are publicly-perceived to be sex-shops, but have not required them to seek a licence because there are no R18 videos being sold. ${ }^{65}$ Conversely, in some instances where an application for a sex-shop license has been refused, a 'sex-shop' has opened anyway - albeit not offering R18 videos. For example, in the process of making an unsuccessful licence application, one owner stated 'the licence laws with regard to sex establishments are very mish-mash. Rather than retreat on refusal we will still open the shop. We'd just adjust the stocks. It's an exercise in stock control, it's not difficult to do. ${ }^{66}$ Although local residents might still argue the store is sex-shop, and the manager market the business as if it were a sex-shop, it is not subject to licensing conditions and, as such, may be able to display lingerie and even sex toys in the window, leaving passers-by in no doubt as to what the business is ${ }^{67}$

Given the absence of licensing, discretion may be even more important in the French context: magazines and DVDs forbidden to minors are sold in most pressstands and tobacconists (most often high up in an 'adult' section). Similarly, 'sex toys' are sold without restriction when they are deemed 'unrealistic' (in terms of colour or shape). This is not a legal definition but a 'commonsense' understanding of what is considered 'obscene', meaning the sale of sex-toys can halt rapidly if there is a concern they may be considered pornographic: 'Until last year, we sold sex-toys, Stephanie explains ... And then we received a complaint from a client, in Limoges, she was having problems with the objects being exposed to children. So we stopped selling them. ${ }^{68}$

\footnotetext{
${ }^{65}$ For example, Bexhill Council's licensing officer stated a sex-shop 'would be able to operate without a licence so long as it sells no more than 50 per cent sex stimulators' cited in Sussex Courier Secret desires in Bexhill (2005) 29 October. The basis of this figure is unclear.

${ }^{66}$ This is Trafford (2005) 26 Sept, p.7.

${ }^{67}$ When Shop Tonight Ltd was refused a sex-shop license in Worthing they opened an unlicensed shop selling lingerie and sex toys, with a view into the shop. See Worthing Herald Bid to halt sexshop receives police backing (2006) 12 January.

${ }^{68} \mathrm{Ph}$. R. [Philippe Rivière] Cachez ce sex toy que je ne saurais voir La Nouvelle République du Centre (2008) February 13, p.2.
} 
In the context of the retail restructuring of the 1990s that effectively gentrified Britain's high streets, the emergence of more 'open' sex retailing has been a widelynoted phenomenon. Elaborating, Clarissa Smith argues that British sex-shops licensed in the 1970s and 1980s remained 'oases of ugliness' whose blacked-out windows created a fear of what lurked within for many female consumers. ${ }^{69}$ In her view, this encouraged a furtive and anonymous consumption of pornography, and reproduced these spaces as male preserves. In contrast, the more open and oftenunlicensed sex-shop challenges the traditional notion of pornography as a male domain (some welcoming men only if they are accompanied by a 'female friend" ${ }^{70}$ ). Commenting on unlicensed 'concept' sex stores aimed at women (including Sh!, Coco de Mer, Bliss, Nua and Ann Summers), Kent and Brown argue 'the new female focus on sex-shops has altered both the design of shops and the products they sell'. Described as women's erotic emporia, 'new-style' sex stores sell sex toys and accessories in a 'relaxed and unpretentious environment, where staff are happy to offer advice over a cup of tea', with the interior imagined as a 'female playspace." ${ }^{71}$ Many also stress that women can take their children into these shops, albeit there is a company policy that areas where sex toys are sold are off-limits to under-18s.

What is notable is that many 'traditional' sex-shops have mimicked some of these strategies in an attempt to make their stores more 'couple-friendly'. Several Harmony stores, for example, have separate doorways leading to licensed and unlicensed sections respectively, one leading to what is described a more 'girlie' ground floor, the other a more 'hard-core' basement. ${ }^{72}$ Arguing that a visit should be as everyday 'as going to any other chain-store in your lunch hour ${ }^{73}$, Nice' $n$ 'Naughty's stores make play of the fact their stores have both male and female staff and offer

\footnotetext{
${ }^{69}$ Smith, C. (2007) op cit, p.170.

${ }^{70}$ www.sh-womenstore.com, accessed 13 Dec 2008.

${ }^{71}$ Malina and Schmidt (1997) op cit, p.356.

${ }^{72}$ A number of Adult World shops in Britain are licensed on a similar basis.

${ }^{73}$ Company spokesperson, cited in Dowdy, C. Sex-shops are making their way to the high street Los Angeles Times (2004) 11 October p.C-4.
} 
'comfortable shopping'. Increasingly, such licensed shops have also sought permission to vary from standard licensing conditions that insist on blanked-out or frosted windows, with many local authorities acceding to requests where the objects to be displayed are 'not outside what is considered decent ${ }^{74}$, and where banners are used to prevent the interior being fully-visible from the street. From the perspective of the owners, such window displays, if 'tasteful' make the 'store far more appealing', potentially breaking down the private/public boundary between licensed and unlicensed space.

Making the stores 'couple-friendly' or 'women-friendly' is all the more important when the goal is to escape the French over-taxation of licentious stores and open in lucrative city centre locations. Many ploys may help the store owner to escape the dreaded 'sex-shop' category: for example, the use of the anglicised 'love shop' instead of 'sex-shop', the refusal to forbid entry to minors, facades designed to appeal to upper-class tastes, the recruitment of professional interior designers, the use of music to induce particular ambiences and so on. Some owners insist on making a distinction between 'sex-shops' and their own stores at every occasion. For instance, one registered the trademark 'developpement durable du couple' ('sustainable development of the couple') to emphasise the (hetero)normality of their business. Another insisted that his store should not be listed in a local guidebook under the 'sex-shop' category. ${ }^{75}$

Given such attempts to evade regulation, a 2007 modification of the 1987 French 'inverse zoning' law re-defined sex-shops as stores selling 'objects of a pornographic character' or 'sex toys' without any lower limitation specified, effectively extending accepted definitions of pornography. ${ }^{76}$ Significantly, this new law also extended the forbidden zone to 200 metres around a school, granting

\footnotetext{
${ }^{74}$ Sandwell Borough Council, Licensing (Miscellaneous) Committee minutes (2008) 17 June, p.2.

${ }^{75}$ Coulmont, op. cit. p.207.

${ }^{76}$ André Lardeux, Rapport ( $\left.n^{\circ} 205\right)$, au nom de la commission des Affaires sociales, sur le projet de loi, modifié par l'Assemblée nationale, réformant la protection de l'enfance, Sénat (2007) 1 February.
} 
more suing possibilities to various associations. A recent shifting jurisprudence is further routinising such legal uncertainty, with the administrative Court of Appeal of Versailles and the supreme administrative court (Conseil d'Etat) suggesting definitions of 'public tranquillity' allow a mayor to forbid the opening of a sex-shop in residential areas. ${ }^{77}$ According to the jurists who studied the decision, this widens notions of 'public tranquillity' and abandons reliance on explicit references to public morality. Yet, because the law does not offer a clear definition, owners are faced with further insecurity. The main threat comes from the possibility of lawsuits initiated by residents, and consequently owners have begun to open sexshops near malls or industrial zones: these benefit from low rentals, parking spaces and from the kind of anonymity that such zones offer. In recent times, the opening of such stores has paralleled the closure of sex-shops in French city centres. ${ }^{78}$

Such examples underline the putative shift from police regulation to a more permanent regulating gaze exercised by the citizenry, effectively institutionalizing a 'regulation by uncertainty' (i.e. uncertainty about what might be considered pornographic). Likewise in Britain, this lack of clarity means that those who run stores where sexual items are on sale manage their store as if it were a sex-shop, being uncertain as to whether they risk prosecution. An example of this is that many unlicensed stores have policies that under-18s should not be admitted alone, despite the fact they have no items it would illegal to sell to 16 or 17-year olds, and many that can legally be sold to all. Window displays of unlicensed stores and sex superstores may also be obscured, allowing no view into the interior, or contain innocuous displays of lingerie even though many sex toys and vibrators could be publicly-displayed without contravening Indecent Advertisements Acts.

\footnotetext{
${ }^{77}$ Conseil d'Etat, juge des référés, Commune de Houilles c. Société Cassandre (2005) 8 June. [N²81084] and Cour administrative d'appel de Versailles (2008) 13 March [N06VE01662] ${ }^{78}$ The libertine tourist guidebooks France Coquine (published since 1998) and Guide du kokin (since 2005) provide evidence of this shift.
} 
What is interesting here is that despite the lack of formal guidelines or rules about how sex-shops should be laid-out and managed, sex-shops and love shops throughout Britain and France have come to share many characteristics. Entering the store, the sales desk is normally immediately visible, subjecting the customer to the gaze of the proprietor, who may ask for proof of age. In front of the sales desk or counter one typically finds racks of DVDs and magazines, organised by category - usually those featuring heterosexual couples and 'glamour girls' first, then more 'specialist' and 'gonzo' titles featuring BDSM or fetish scenarios, lesbian and girlon-girl sex or public sex. In many stores DVDs featuring gay male sex are less visible, the assumption seeming to be that these will be of marginal appeal to most customers. At the front of the store, lingerie and adult-themed 'fancy dress' may be on display: normally sex toys, vibrators, stimulants and lubricants are nearer the back, but in clear view of the sales desk: fetish-wear and BDSM accessories, as well as 'gay' clothing/paraphernalia may be in a separate room, or in the basement or first-floor.

The layout of the sex-shop thus materialises particular assumptions about sexual morality, with 'harder' items only becoming visible once one has negotiated the 'softer'. Even in Ann Summers, now ubiquitously offering 'cheap and cheerful sexual paraphernalia' on British high streets ${ }^{79}$, 'clothing is displayed in standardised units, which become more specialised until false fur and leather finally give way to sex toys which are discretely, almost apologetically, hidden in a rear alcove'. ${ }^{80}$ Touristic guidebooks emphasize this: the Guide Musardine du Paris Sexy describes with appreciation a 'quasi-ideal store, with lingerie at the window and a progression from banal objects at the entry to the pornographic inferno at the back of the store $^{81}$. Concerns about visibility and morality thus appear to entwine with marketing considerations, creating a standardised layout. Thus, even where there

\footnotetext{
${ }^{79}$ Attwood, F. Introduction, Mainstreaming Sex (2009) London: IB Tauris, p.xv.

${ }^{80}$ Kent, T. and Brown, R.B., op cit, p.209.

${ }^{81}$ Dannam M., Guide musardine du Paris sexy (2006) Paris, La Musardine p.60.
} 
are no rules, shop-owners act as if there are rules - the rules coming from the regulated as much as the regulators.

\section{Conclusions}

This paper has considered how shops selling pornography and sexual materials have been regulated in Britain and France over the last four decades. In both cases, there has been an important shift from the use of criminal law (enforced through punitive policing and stock seizure) to more diffuse forms of control in which the management of risk is devolved to the owners and managers of shops. In Britain, this has been through licensing - a technique of governance that instrumentalises social actors' capacity for self-governance rather than relying on panoptic surveillance. ${ }^{82}$ In France this has been through the progressive outsourcing of the regulating gaze from the police to the 'riverains' (local residents) and a tentative legal exclusion of sex-shops from city centres.

In both cases, such regulation allows the state to claim that it is uninterested in questions of private sexual morality whilst allowing it to address issues of public order, principally by enacting a legal geography in which sex-shops are located away from those areas where their presence might be problematic. Yet beyond this form of spatial control, and the associated maintenance of a clear boundary between the public and private realm, the state and law generally leaves decisions about the running of the business to the premise operator, who takes on responsibility for ensuring that the shop is well-run and has no detrimental impacts on its locality. ${ }^{83}$ In general terms, this has favoured the more corporate, 'well-managed' sex-shops, and encouraged the development of more 'open', women- or couple-friendly

\footnotetext{
${ }^{82}$ Hadfield, P. Bar wars (2006) Cullompton, Willan.

${ }^{83}$ Manchester, C., Poppleston, S and Allen, J. Alcohol and entertainment licensing law (2007) London: Routledge Cavendish, p.6.
} 
stores. While it is tempting to describe this as a planned regulatory outcome, the gentrification of sex-shops is perhaps better viewed as the cumulative outcome of a series of situated decisions that had no a priori predicted outcomes. Indeed, the upscaling of sex-shops is also connected to wider shifts in the sex industry, which in the last forty years has changed from being a 'small, privately-owned, illegitimate and almost feudal set of businesses dependent on local sheriffs looking the other way' to being a 'multi-billion dollar business dominated by corporations ${ }^{84}$ This expansion of sex commerce, coupled with the putative mainstreaming of sexual imagery, has changed the way people are able to access sexual materials, creating new synergies between the physical spaces of sex retailing and an ever-expanding Internet pornography industry. ${ }^{85}$ In this respect - and given sex-shops are becoming more astute in their Internet marketing strategies - it is tempting to speculate that the increasing number who buy sexual materials online may be less concerned about what (and whom) they might encounter within sex-shops, meaning that sex-shops may become a more accepted, and less contested, space in the future.

\footnotetext{
${ }^{84}$ Hausbeck, K., and Brents, B. McDonaldization of the sex industry? (2002) In Ritzer, G. (ed) McDonaldization: The reader, Thousand Oaks, CA: Pine Forge Press, p.91-107.

${ }^{85}$ Zook, M.A. Underground globalization: Mapping the space of flows of the Internet adult industry (2003) Environment and Planning A 35 1261-1286.
} 